\title{
Fibroinflammatory Polyps Masquerading as Inverted Papilloma of Inferior Turbinate
}

\author{
Ji-Hwan Park, $\mathrm{MD}^{1}$, Seon-Lin Kim, $\mathrm{MD}^{1}$, Kyung-Un Choi, $\mathrm{MD}, \mathrm{PhD}^{2}$ and Kyu-Sup Cho, $\mathrm{MD}, \mathrm{PhD}^{1}$ \\ ${ }^{1}$ Department of Otorhinolaryngology-Head \& Neck Surgery, Pusan National University Hospital, Busan; and \\ ${ }^{2}$ Department of Pathology, Pusan National University School of Medicine, Pusan National University Hospital, \\ Busan, Korea
}

\begin{abstract}
- ABSTRACT -
Nasal polyps are a chronic inflammatory disease of the mucous membranes in the nose and paranasal sinuses. Inverted papilloma is a benign, locally aggressive neoplasm that arises in the nasal cavity and is associated with squamous cell carcinoma. Although most nasal polyps are benign and noncancerous, they should be distinguished from inverted papillomas, which have more serious consequences. Here, we describe the first case of fibroinflammatory polyp originated from inferior turbinate masquerading as inverted papilloma, which was successfully removed via transnasal endoscopic approach. (J Clinical Otolaryngol 2017;28:273-276)
\end{abstract}

KEY WORDS : Nasal polyps $\cdot$ Papilloma $\cdot$ Turbinates $\cdot$ Neoplasms.

\section{Introduction}

Nasal polyps are a chronic inflammatory disease of the mucous membranes in the nose and paranasal sinuses. ${ }^{1)}$ Nasal polyps usually have a teardrop shape and tend to have a smooth surface. ${ }^{1,2)}$ Although most nasal polyps are benign and noncancerous, they should be distinguished from inverted papillomas, which are benign epithelial tumors and have more serious consequences. Herein, we report a case of fibroinflammatory polyps originated from inferior turbinate masquerading as inverted papilloma, which was successfully removed via transnasal endoscopic approach.

논문접수일 : 2017년 9월 19일

논문수정일 : 2017년 10월 18일

심사완료일 : 2017년 11월 3일

교신저자 : 조규섭, 49241 부산광역시 서구 구덕로 179

부산대학교 의학전문대학원 이비인후과학교실

전화 : (051) 2224-4818·전송 : (051) 246-8668

E-mail:choks@pusan.ac.kr

\section{Case Report}

A 44-year-old male presented left sided nasal obstruction, rhinorrhea, and postnasal drip for several months. The patient's medical history was otherwise unremarkable. Nasal endoscopy revealed a polypoid mass with papillary surface filling the left inferior meatus (Fig. 1). A computed tomography (CT) scan of the paranasal sinus showed enhancing polypoid mass in left inferior meatus with adjacent bony remodeling and erosion (Fig. 1B, C). From these findings, the lesion was suspected to be a inverted papilloma. A transnasal endoscopic removal of polypoid mass following septoplasty under general anesthesia was performed. Using nasal scissor and microdebrider (Medtronic Xomed, Jacksonville, FL), the mass and the anterior one third of inferior turbinate were removed completely with a safety margin, because of the possibility of inverted papilloma (Fig. 2). Histopathologic findings showed respiratory epithelial lining, edematous stroma with hyperplastic mucous gland, and the infiltration of inflammatory cells mainly lym- 

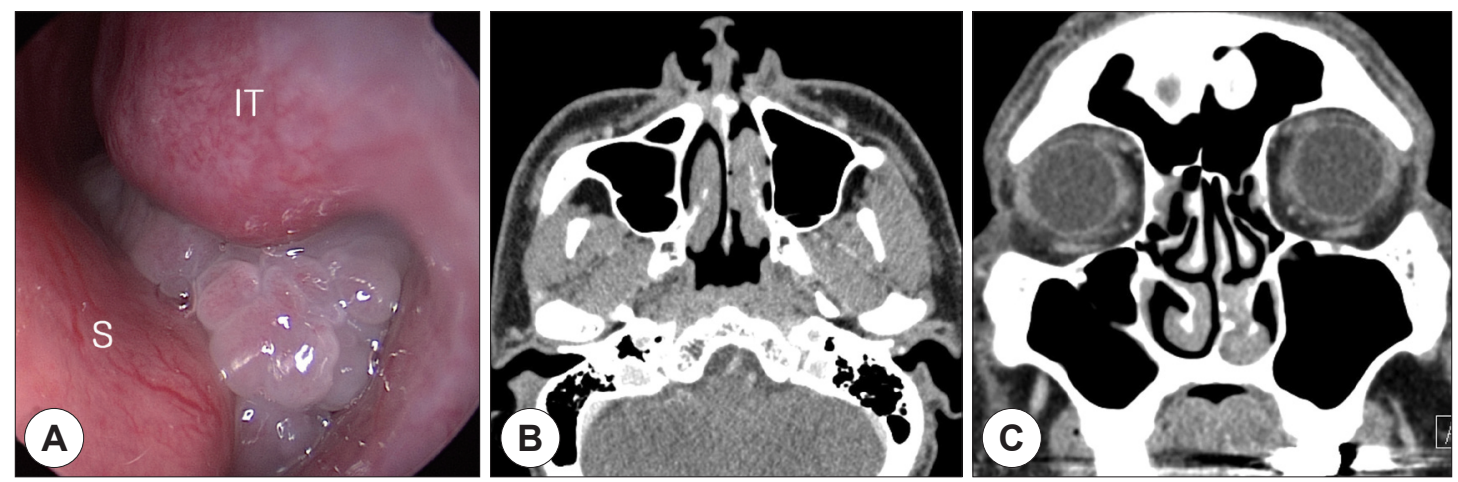

Fig. 1. Preoperative endoscopy and computed tomography $(\mathrm{CT})$. Nasal endoscopy $(\mathrm{A})$ shows a polypoid mass with papillary surface filling the left inferior meatus. Contrast-enhanced axial (B) and coronal (C) CT images show enhancing polypoid mass in left inferior meatus with bony remodeling and erosion of inferior turbinate (IT). Nasal septum $(\mathrm{S})$ deviation to the left side is noted.
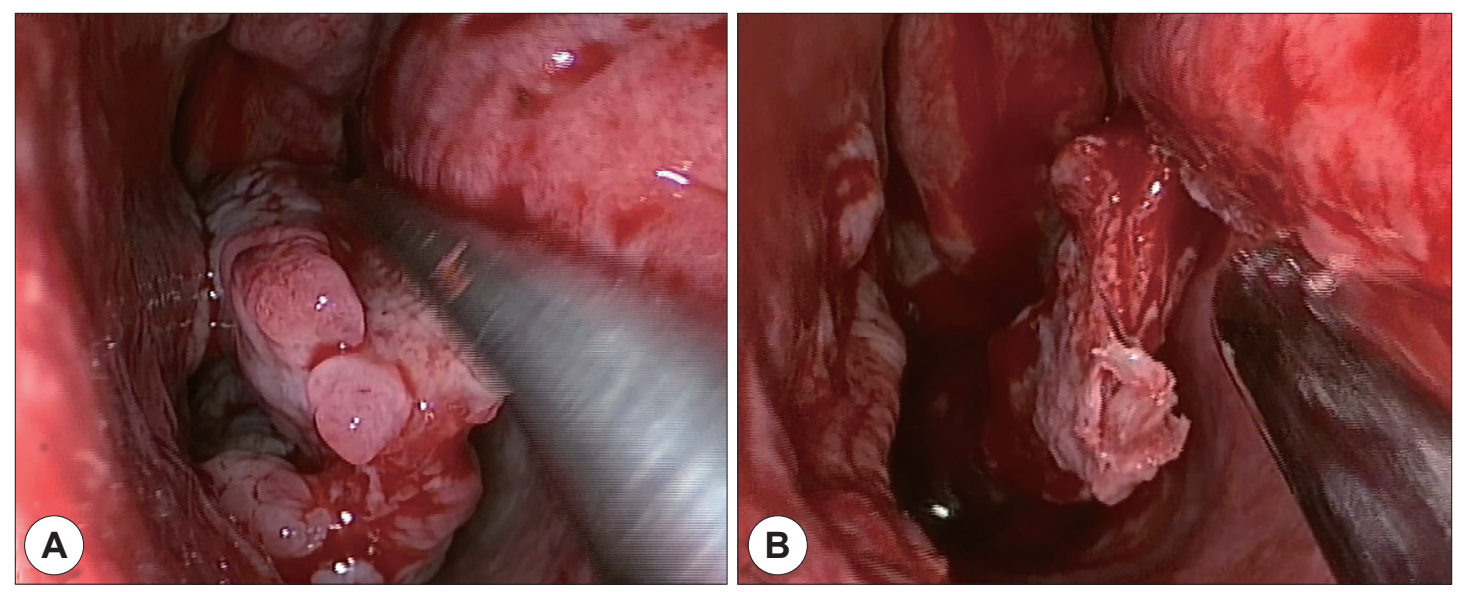

Fig. 2. Intraoperative endoscopic findings. A : Using nasal scissor, the left polypoid mass and the anterior one third of inferior turbinate were removed completely with a safety margin. B : The inferior turbinate mucosa was trimmed with straight blade of a microdebrider.

phocytes and neutrophils with fewer eosinophils. These findings were consistent with fibroinflammatory nasal polyps (Fig. 3). The patient had an uneventful recovery and endoscopic examinations performed at 6 months postoperatively demonstrated no evidence of recurrence.

\section{Discussion}

Nasal polyps is characterized by an edematous mass of hyperplastic epithelium and lamina propria prolapsing into the nose, leading to nasal obstruction, hy- persecretion, loss of the sense of smell, and reduced quality of life. ${ }^{1)}$ Histopathologically, nasal polyps are characterized by the infiltration of inflammatory cells, such as eosinophils, neutrophils, and lymphocytes. ${ }^{3)}$ Although polyps may be broadly classified into four types based on histologic characteristics, the eosinophilic edematous type and the fibrotic inflammatory type are most commonly seen in clinical practice. Eosinophilic nasal polyps are characterized by edematous stroma with a large number of eosinophils, but fibroinflammatory nasal polyps have a higher frequency of lymphocyte and neutrophil infiltration with fewer eo- 

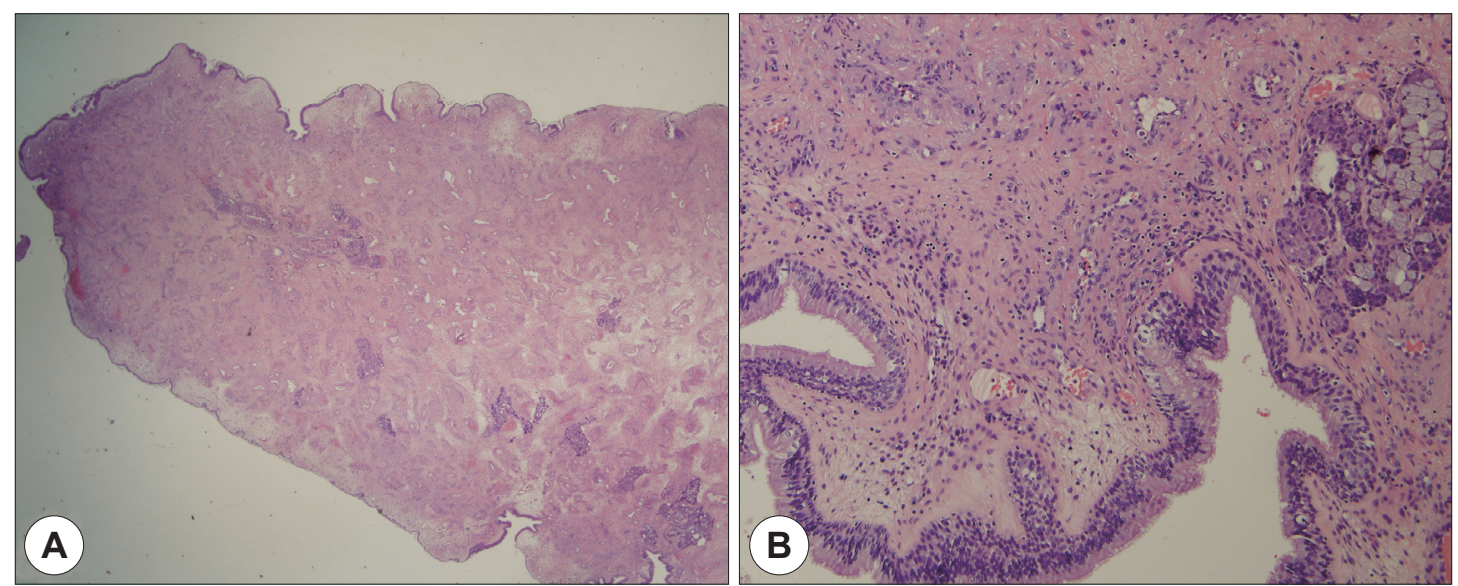

Fig. 3. Histopathologic findings of fibroinflammatory polyps. A : A polypoid mass is covered by the respiratory epithelium $(H \& E, \times 10)$. B : A large number of inflammatory cells mainly lymphocytes and neutrophils are infiltrated in the subepithelial region $(H \& E, \times 200)$.

sinophils. ${ }^{1,4)}$

Several conditions such as malignant tumor and inverted papilloma may masquerade as simple polyps and may not always be clinically conclusive especially when polyps are unilateral. Therefore, unilateral nasal polyps should always be regarded with suspicion and histology is needed in order to exclude malignancy and inverted papilloma. ${ }^{5)}$ Although benign-looking polyps diagnosed as an inverted papilloma are less frequently reported, ${ }^{6,7)}$ nasal polyps masquerading as inverted papilloma has not been reported. This report described fibroinflammatory polyp detected histopathologically in a clinically suspected case of inverted papilloma.

The characteristic attributes of inverted papilloma are its tendency to recur, its destructive capacity, and its propensity to be associated with malignancy. ${ }^{8,9} \mathrm{Sev}$ eral lesions may be confused or need to be separated from inverted papillomas. Furthermore, inverted papillomas may be misdiagnosed as inflammatory polyps. Although nonspecific symptom and clinical presentation make inverted papilloma a diagnostic and therapeutic challenge, papillomas have irregular surfaces and are warts, but polyps have smooth surfaces. It is difficult to make a diagnosis as inverted papilloma with radiologic findings. However, there is a high incidence of unilateral involvement and bone remodeling in inverted papilloma compared with nasal polyps. ${ }^{10,11)}$ In the present case, the tumor was initially assumed to be an inverted papilloma, because unilateral polypoid mass showed a convoluted and wrinkled surface with bony remodeling and erosion of inferior turbinate in the CT scan. However, histopathology showed a marked inflammatory infiltrate containing mostly lymphocytes and metaplastic changes of the overlying epithelium. These findings were consistent with a fibroinflammatory polyp. Although not all nasal polyps need to be removed immediately, when they should be distinguished from inverted papillomas, surgical excision and histopathological examination is required for timely management of possible tumors that may have more serious consequences.

Fibroinflammatory nasal polyp with unilateral involvement may have a typical granular mulberry-like appearance and radiologic evidence of adjacent bone erosion, which could be clinically suspected as inverted papilloma. Therefore, in addition to endoscopic and radiographic finding, biopsies should be taken for histopathologic examination to confirm diagnosis and guide further management. 


\section{REFERENCES}

1) Pawankar R. Nasal polyposis: an update: editorial review. Curr Opin Allergy Clin Immunol 2003;3(1):1-6.

2) Kirtsreesakul V. Update on nasal polyps: etiopathogenesis. J Med Assoc Thai 2005;88(12):1966-72.

3) Shi J, Fan Y, Xu R, Zuo K, ChengL, Xu G, et al. Characterizing T-cell phenotypes in nasal polyposis in Chinese patients. J Investig Allergol Clin Immunol 2009;19(4):27682.

4) Kim JW, Hong SL, Kim YK, Lee CH, Min YG, Rhee CS. Histological and immunological features of non-eosinophilic nasal polyps. Otolaryngol Head Neck Surg 2007;137 (6):925-30.

5) Kale SU, Mohite U, Rowlands D, Drake-Lee AB. Clinical and histopathological correlation of nasal polyps: are there any surprises?. Clin Otolaryngol Allied Sci 2001;26(4): 321-3.

6) Garavello W, Gaini RM. Incidence of inverted papilloma in recurrent nasal polyposis. Laryngoscope 2006;166(2): 221-3.

7) Segal N, Gluck O, Bavnik Y, Plakht Y, Yakirevitch A. The usefulness of preoperative biopsy in unilateral nasal masses. Allergy Rhinol 2014;5(2):53-5.

8) Robinson S, Tan LW, James C, Karakousis A, Wormald PJ. Do nasal polyps and inverted papilloma have similar disorders in cell cycle regulation?. Am J Rhinol 2006;20(6): $637-40$.

9) Roh HW, Lee HS, Park DY, Gary procop. A novel pathological grading system of sinonasal inverted papilloma. J Clinical Otoparyngol 2004;15:109-18.

10) Head CS, Sercarz JA, Luu Q, Collins J, Blackwell KE. Radiologic assessment of inverted papilloma. Acta Otolaryngol 2007;127(5):515-20.

11) Jung JH, Kim M, Mun SJ, Rho HJ. Stage surgery on inverted papilloma which invaded lacrimal sac, periorbita, ethmoid and frontal sinus. J Clinical Otolaryngol 2016;27 (1):143-8. 